\title{
POLA PERUBAHAN HARGA DAN MARJIN PEMASARAN BAHAN PANGAN DI MASA PANDEMI COVID-19
}

\author{
Herawati $^{1}$, dan Harianto ${ }^{2}$ \\ 1,2)Departemen Agribisnis, Fakultas Ekonomi dan Manajemen, Instutut Pertanian Bogor \\ Jl. Kamper Wing 4 Level 5 Kampus IPB Dramaga, Indonesia \\ e-mail: ${ }^{1)}$ hera@apps.ipb.ac.id
}

(Diterima 21 Oktober 2021/Revisi 4 Desember 2021/Disetujui 15 Desember 2021)

\begin{abstract}
Food products are the main concern for the government and people of Indonesia. Changes in food prices have significant effects on the welfare of the population. Covid-19 pandemic has significantly affected community activities and the food agribusiness system. This study analyzes patterns of changes in prices and marketing margins of seven main food products in Indonesian food consumption i.e. rice, shallots, garlic, red chillies, cayenne pepper, cooking oil, and sugar, after the Covid-19 pandemic by presenting descriptive statistics of daily food prices data from the National Strategic Food Price Information Center (PIHPSN). Based on empirical results, except for shallots and cooking oil, most food prices at various market levels have fallen during the Covid-19 pandemic. On the other hand, the risk of food prices at various levels of the market has been increasing. During the Covid-19 pandemic, the magnitude and variability of marketing margins along the marketing chain also have been increasing. These findings imply the urgency of Institutional policies that can increase market transparency and competition appears to be more effective in the long term at reducing the price shocks caused by Covid-19 at various levels of the market than price interventions.
\end{abstract}

Keywords: marketing chain, modern market, price risk, traditional market, wholesaler

\begin{abstract}
ABSTRAK
Bahan pangan masih menjadi komoditas strategis bagi pemerintah dan masyarakat Indonesia. Perubahan harga-harga pangan berpengaruh signifikan bagi kesejahteraan penduduk. Pandemi Covid-19 secara nyata memengaruhi aktivitas masyarakat dan sistem agribisnis pangan. Penelitian ini ditujukan untuk menganalisis pola perubahan harga dan marjin pemasaran bahan pangan (beras, bawang merah, bawang putih, cabai merah, cabai rawit, minyak goreng, dan gula) setelah adanya pandemi Covid-19. Metode penelitian yang digunakan adalah statistik deskriptif melalui penghitungan rata-rata sederhana, marjin, dan koefisien variasi terhadap data hargaharga bahan pangan harian yang berasal dari Pusat Informasi Harga Pangan Strategis Nasional (PIHPSN). Berdasarkan hasil analisis diketahui bahwa, kecuali bawang merah dan minyak goreng, harga-harga bahan pangan di berbagai tingkatan pasar turun di masa pandemi Covid19. Namun, risiko harga bahan pangan di berbagai tingkatan pasar meningkat. Pada masa pandemic Covid-19 besaran dan variabilitas marjin pemasaran di sepanjang rantai pemasaran juga meningkat. Kebijakan kelembagaan yang mampu meningkatkan transparansi dan kompetisi pasar tampaknya lebih efektif dalam jangka panjang untuk mengurangi guncangan harga akibat Covid-19 di berbagai tingkat pasar daripada intervensi harga.
\end{abstract}

Kata kunci: pasar modern, pasar tradisional, pedagang besar, rantai pemasaran, risiko harga

\section{PENDAHULUAN}

Pergerakan harga bahan pangan, terutama bahan pangan pokok, masih menjadi perhatian besar bagi pemerintah dan masyarakat. Pengeluaran untuk pangan masih menduduki pangsa yang penting dalam pengeluaran rumah tangga di Indonesia, terutama rumah tangga yang berpendapatan rendah. Pangsa pengeluaran pangan rumah tangga berpendapatan rendah relatif jauh lebih tinggi daripada 
rumah tangga berpendapatan tinggi. Ratarata pangsa pengeluaran rumah tangga yang berada pada kelompok pendapatan 20 persen termiskin pada tahun 2007, berdasarkan data Indonesian Family Life Survey, adalah sebesar 61 persen (Pangaribowo, 2014).

Perubahan harga pangan secara langsung dapat memengaruhi kesejahteraan. Harga pangan masih menjadi komponen penting bagi penghitungan garis kemiskinan. Harga pangan yang meningkat dapat berakibat pada meningkatnya jumlah penduduk miskin. Harga pangan juga menjadi bagian dalam penghitungan upah minimum regional (UMR). Harga pangan yang meningkat di tingkat konsumen dapat berakibat pada meningkatnya dorongan untuk meningkatkan UMR, yang pada akhirnya juga berakibat pada menurunnya daya saing berbagai produk yang dihasilkan oleh sektor-sektor yang mengandalkan tenaga kerja sebagai faktor produksi utama. Oleh sebab itu, stabilitas harga pangan senantiasa menjadi perhatian pemerintah, karena secara langsung memengaruhi kesejahteraan. Di berbagai negara sedang berkembang, pandemi Covid-19 berakibat pada terganggunya rantai distribusi pangan dan menurunkan ketahanan pangan masyarakat (Nchanji et.al., 2020).

Harga pangan di tingkat konsumen tentunya secara langsung dipengaruhi oleh kondisi permintaan dan penawaran pangan di pasar eceran. Permintaan pangan terutama dipengaruhi peningkatan pendapatan dan pening- katan jumlah penduduk. Perekonomian Indonesia yang secara konsisten terus tumbuh, sebelum adanya pandemi Covid-19, tentunya merupakan cerminan dari pendapatan rumah tangga yang juga meningkat. Apabila peningkatan pendapatan rumah tangga ini tidak disertai dengan peningkatan ketersediaan pangan yang mencukupi, maka harga pangan akan terdorong naik. Pandemi Covid-19 yang diikuti oleh pembatasan aktivitas manusia berakibat pada terganggunya aktivitas perekonomian di seluruh dunia, terutama di sektor pertanian, baik pada sisi produksi, rantai pemasaran, maupun pada sisi konsumsi (Poudel et.al., 2020; Siche, 2020). Harga pangan yang naik atau turun di masa pandemi Covid-19 ditentukan tidak saja oleh para pelaku yang ada di tingkat konsumen akhir, tetapi juga ditentukan oleh perilaku produsen pangan dan para pelaku yang berada di sepanjang rantai pemasarannya.

Akibat pandemi Covid-19, pasar pangan di berbagai negara mengalami gangguan yang relatif sama. Kesamaan gangguan ini bersumber dari karakteristik penyebaran virus SARS-Cov-2 yang menyebar melalui interaksi antar individu dengan jarak yang dekat. Berbagai pemerintahan menetapkan kebijakan-kebijakan yang diharapkan mampu mencegah intensitas interaksi antar manusia. Pembatasan interaksi antar orang ini juga berakibat pada terhambatnya aliran barang antar pasar, dari tingkat produsen sampai pada tingkat konsumen. Tabel 1 menunjuk-

Tabel 1. Permasalahan yang Dihadapi Pertanian di Empat Negara Besar pada Masa Pandemi Covid-19

\begin{tabular}{|c|c|c|c|}
\hline $\begin{array}{c}\text { India } \\
\text { (Sahoo \& Samal, 2020; } \\
\text { Urumugam } \text { et.al., 2020) }\end{array}$ & $\begin{array}{c}\text { Amerika Serikat } \\
\text { (Tanger, 2020) }\end{array}$ & $\begin{array}{c}\text { Cina } \\
\text { (Huang, 2020; Pan et.al., } \\
\text { 2020) }\end{array}$ & Indonesia* \\
\hline $\begin{array}{l}\text { - Penutupan ekspor produk } \\
\text { pertanian. } \\
\text { - Berkurangnya tenaga kerja } \\
\text { panen dan akses terhadap } \\
\text { input pertanian. } \\
\text { - Terganggunya rantai } \\
\text { pasok di pedesaan. } \\
\text { - Hambatan transportasi } \\
\text { produk pangan antar } \\
\text { daerah. } \\
\text { - Pembatasan dan } \\
\text { penutupan pasar eceran } \\
\text { pangan. }\end{array}$ & $\begin{array}{l}\text { - Penawaran tenaga kerja di } \\
\text { tingkat usahatani dan } \\
\text { pengolahan turun. } \\
\text { - Permintaan produk } \\
\text { pertanian (domestik dan } \\
\text { internasional) turun. } \\
\text { - Semakin sulit untuk } \\
\text { memperoleh akses } \\
\text { terhadap sumber finansial. } \\
\text { - Disrupsi pada rantai } \\
\text { pasok. } \\
\text { - Gangguan pasar di tingkat } \\
\text { retail. }\end{array}$ & $\begin{array}{l}\text { - Terhambatnya rantai pasok } \\
\text { produk pertanian. } \\
\text { - Pendapatan petani dari upah } \\
\text { tenaga kerja dan penjualan } \\
\text { produk usahatani } \\
\text { mengalami penurunan. } \\
\text { - Terbatasnya tenaga kerja } \\
\text { pertanian karena adanya } \\
\text { karantina wilayah. } \\
\text { - Terganggunya pasokan } \\
\text { benih, pupuk, pestisida } \\
\text { karena pembatasan dan } \\
\text { penutupan transportasi. }\end{array}$ & $\begin{array}{l}\text { - Ancaman penghentian } \\
\text { impor oleh negara } \\
\text { tujuan karena produk } \\
\text { yang tercemar SARS- } \\
\text { Cov-2. } \\
\text { - Terganggunya rantai } \\
\text { pasok pangan di sisi } \\
\text { hilir. } \\
\text { - Permintaan bahan } \\
\text { pangan turun, terutama } \\
\text { dari hotel, industri } \\
\text { pengolahan, dan } \\
\text { restoran. }\end{array}$ \\
\hline
\end{tabular}


kan bahwa dampak dari pengurangan interaksi antar manusia terhadap pertanian terutama adalah terganggunya rantai pasok produk dari tingkat petani sampai ke tingkat eceran. Produk-produk pertanian yang mudah rusak, seperti produk hortikultura dan sayuran, mengalami penurunan harga di tingkat petani dan kenaikan harga di tingkat eceran. Kondisi melebarnya marjin pemasaran akibat pandemi Covid-19 dialami oleh produk pertanian di Cina (Zhou et.al., 2020). Marjin pemasaran produk pertanian yang melebar antara tingkat petani dan tingkat konsumen tersebut disebabkan oleh meningkatkan biaya pemasaran.

Pasar pangan di India memperoleh intervensi yang dominan di India, dan aktivitas pemasaran sebagian besar melibatkan institusi publik. Pandemi Covid-19 menyebabkan kemampuan fiskal semakin terbatas, dan alokasi anggaran yang disalurkan untuk menangani pasar produk pangan menjadi jauh berkurang. Kemampuan negara untuk menyerap produk pertanian yang dihasilkan petani menjadi turun, dan petani mengalami kesulitan menjual produk usahataninya (Tabel 1).

Pandemi Covid-19 tidak hanya mempengaruhi pasar dalam negeri tetapi juga pasar internasional. Tabel 1 juga menunjukkan pertanian di Amerika Serikat mengalami penurunan ekspor produk pertaniannya di pasar internasional. Sebaliknya, ekspor beberapa produk pertanian Indonesia mengalami peningkatan. Berdasarkan data BPS, ekspor hasil pertanian pada bulan Januari sampai bulan September 2020 mengalami kenaikan. Produk pertanian yang mengalami peningkatan ekspor secara signifikan adalah produk hortikultura, kelapa, tanaman rempah mengalami dampak negatif dari turunnya permintaan produk di pasar internasional. Keadaan ini berbeda dengan Indonesia yang mengalami peningkatan ekspor produk pertanian. Berdasarkan data yang dikeluarkan oleh Badan Pusat Statistik, ekspor pertanian Indonesia dari bulan Januari sampai September 2020 mengalami kenaikan sebesar 9.70 persen dibandingkan periode yang sama pada tahun sebelumnya. Produk pertanian yang mengalami lonjakan ekspor adalah kelapa, produk hortikultura, maupun tanaman rempah seperti cengkeh dan kayu manis. Negara-negara maju tampaknya meningkatkan permintaan terhadap komoditas yang dianggap lebih menyehatkan dan yang memiliki pengaruh baik bagi pertahanan tubuh menghadapi virus SARS-CoV-2. Penelitian Min et.al., (2020) di Cina menunjukkan bahwa pandemi Covid19 meningkatkan pengetahuan konsumen terhadap keamanan pangan yang mereka konsumsi, dan peningkatan pengetahuan ini kemudian meningkatkan perilaku konsumsi pangan yang lebih aman.

Pengetahuan yang memadai terhadap pengaruh pandemi Covid-19 terhadap pasar pangan, merupakan syarat keharusan bagi upaya-upaya untuk menjamin stabilitas pangan baik di tingkat konsumen maupun di tingkat produsen. Penelitian ini ditujukan untuk mengenali pola perubahan harga pangan dan marjin pemasaran di berbagai tingkatan sepanjang rantai pemasaran pangan. Perubahan kondisi ekonomi akibat pandemi Covid-19 yang berbeda di berbagai tingkatan pasar di sepanjang rantai pemasaran akan memunculkan pola perubahan harga dan marjin pemasaran yang juga berbeda. Kebaruan atau novelty dari penelitian ini bukanlah terletak pada aspek metodologinya, tetapi berada pada pemberian bukti bahwa pandemi Covid-19 memiliki pengaruh yang berbeda-beda antar komoditas pangan. Perbedaan yang muncul diperkirakan tidak saja dari karakteristik komoditas yang diperjualbelikan, tetapi juga karena struktur pasar dan ada atau tidak adanya kebijakan pemerintah. Penelitian ini pada dasarnya bersifat deskriptif eksploratif. Penelitian diharapkan dapat mendeskripsikan fenomena pengaruh pandemi Covid-19 terhadap pola perubahan harga pangan dan pola perubahan marjin pemasaran. Sebagai penelitian eksploratif, hasilnya diharapkan tidak saja memberikan informasi yang bermanfaat bagi kebijakan publik, tetapi juga dapat menuntun pada pertanyaan-pertanyaan (research questions) penelitian yang lebih mendalam, terutama 
tentang perubahan perilaku para pelaku pasar di sepanjang rantai pemasaran produk agribisnis.

\section{METODE}

Pasar pangan di Indonesia memiliki karakteristik yang berbeda-beda antar komoditas. Perbedaan karakteristik tersebut dapat diakibatkan oleh karakteristik produk, struktur pasar, maupun intensitas intervensi pemerintah. Pangan yang memerlukan pengolahan sebelum siap untuk dijual sampai ke tangan konsumen tentunya memiliki pasar yang berbeda dengan produk pangan segar yang langsung dijual ke konsumen akhir. Demikian juga, bahan pangan yang dapat disimpan dalam waktu relatif lama akan memiliki karakteristik pasar yang berbeda dengan pasar produk yang cepat rusak (perishable). Struktur pasar yang cenderung bersifat monopolistik ataupun monopsonistik secara teoritis memiliki perilaku yang berbeda dengan struktur pasar pangan yang para pelakunya bertindak sebagai penerima harga. Pasar pangan yang memiliki intensitas keterlibatan pemerintah yang relatif tinggi tentunya juga berbeda dengan pasar yang sepenuhnya bebas intervensi. Pemerintah sering melalui berbagai kebijakan yang diambilnya melakukan intervensi di pasar pangan. Kebijakan atau intervensi pemerintah di pasar pangan pada dasarnya ditujukan untuk mengatasi kegagalan pasar yang terjadi maupun ditujukan untuk memperbaiki distribusi pendapatan.

Pilihan atas komoditas pada penelitian ini diharapkan mampu menangkap perbedaan karakteristik pasar pangan yang ada, baik dari sisi produk, struktur pasar, maupun intensitas kebijakan pemerintah. Penelitian ini memanfaatkan monitoring harga harian yang dilakukan oleh pemerintah terhadap berbagai komoditas pertanian yang dianggap "strategis". Pergerakan harga bahan pangan yang strategis umumnya memperoleh perhatian yang relatif besar dari pemerintah. Meskipun bahan pangan umumnya tidak termasuk dalam perhitungan core inflation, tetapi bahan pangan dianggap memiliki harga yang bersifat volatile sehingga perlu dicermati. Dalam penelitian ini juga memasukkan produk pangan yang dihasilkan oleh industri pengolahan, yaitu minyak goreng dan gula. Kedua bahan pangan ini memiliki keterkaitan ke belakang dan ke depan (backward and forward linkages) yang besar dalam rantai nilai agribisnis. Tabel 2 menyajikan bahan pangan yang dipilih dalam penelitian ini, beserta deskripsi umum karakteristik pasarnya.

\section{SUMBER DAN METODE ANALISIS DATA}

Data yang digunakan dalam penelitian ini sepenuhnya bersumber dari Pusat Informasi Harga Pangan Strategis Nasional (PIHPSN) yang merupakan data harga harian berbagai jenis bahan pangan. Jenis data yang dipilih diharapkan mampu mengungkap tidak saja kondisi harga dan marjin sebelum dan setelah adanya pandemi Covid-19, tetapi juga menangkap variasi harga jangka pendek dengan lebih detail dibandingkan apabila data tersebut merupakan data rataan bulanan. Kebijakan pembatasan aktivitas penduduk dalam rangka menekan proses penyebaran virus SARS-Cov-2 berbeda-beda waktunya antar daerah di Indonesia. Kebijakan tersebut tidak diperlakukan sepanjang waktu selama pandemi, melainkan diberlakukan sesuai dengan naik turunnya kondisi keparahan sebaran SARS-Cov-2 dari waktu ke waktu. Dengan menggunakan data harian, diharapkan dinamika kebijakan yang terkait dengan pandemi Covid-19 dapat ditangkap dengan baik dalam penelitian ini.

Harga yang dicermati dalam penelitian ini adalah harga pangan di tingkat produsen, di tingkat pedagang besar, di tingkat pasar tradisional, dan di tingkat pasar modern. Sedangkan marjin pemasaran yang dikaji adalah marjin pemasaran antara pasar: 1) tingkat produsen dengan tingkat pedagang besar; 2) tingkat produsen dengan tingkat pasar modern; 3) tingkat produsen dengan tingkat pasar tradisional; 4) tingkat pedagang besar dengan tingkat pasar modern; dan 5) tingkat pasar pedagang besar dengan tingkat 
Tabel 2. Karakteristik Bahan Pangan yang Dipilih dalam Penelitian

\begin{tabular}{|c|c|c|c|}
\hline Komoditas & Karakteristik Produk & Karakteristik Pasar & Intervensi Pemerintah \\
\hline Beras & $\begin{array}{l}\text { Dapat disimpan dalam } \\
\text { waktu tahunan (Pahulu } \\
\text { et.al., 2007). }\end{array}$ & $\begin{array}{l}\text { Pada tingkatan awal (petani sampai di } \\
\text { penggilingan padi) pasar bersifat } \\
\text { oligopsoni dan setelah itu pasar lebih } \\
\text { bersifat oligopoli (JICA, 2018). }\end{array}$ & Relatif tinggi (Nuryanti, 2018 \\
\hline $\begin{array}{l}\text { Bawang } \\
\text { merah }\end{array}$ & $\begin{array}{l}\text { Dapat disimpan dalam } \\
\text { waktu sekitar } 1 \text { bulan di } \\
\text { dalam ruangan (Tesfa } \\
\text { et.al., 2015) }\end{array}$ & $\begin{array}{l}\text { Dari pasar di tingkat petani sampai pada } \\
\text { pedagang besar, pasar berstruktur } \\
\text { oligopsoni, tetapi menjadi oligopoli di } \\
\text { tingkatan pedagang besar sampai di } \\
\text { tingkat eceran (JICA, 2018). }\end{array}$ & $\begin{array}{l}\text { Relatif rendah (Rahmawati, } \\
\text { 2018). }\end{array}$ \\
\hline $\begin{array}{l}\text { Bawang } \\
\text { putih }\end{array}$ & $\begin{array}{l}\text { Dapat disimpan dalam } \\
\text { waktu sekitar } 5 \text { bulan } \\
\text { dalam ruangan } \\
\text { (Vatsyayan } \text { et.al., 2014). }\end{array}$ & $\begin{array}{l}\text { Meskipun terdapat isu kartel, pasar } \\
\text { cenderung berstruktur monopolistik } \\
\text { competition (Amanda et.al., 2016). }\end{array}$ & Medium (Amanda et.al., 2016 \\
\hline $\begin{array}{l}\text { Cabai } \\
\text { merah }\end{array}$ & $\begin{array}{l}\text { Produk mudah rusak sejak } \\
\text { dari panen, sortasi, dan } \\
\text { penyimpanan sampai di } \\
\text { tangan konsumen } \\
\text { (Nurjanah } \text { et.al., 2014). }\end{array}$ & $\begin{array}{l}\text { Dari petani sampai pada pedagang } \\
\text { besar, pasar bersifat oligopsoni, dan dari } \\
\text { pedagang besar sampai tingkat eceran } \\
\text { berstruktur oligopoli (JICA, 2018). }\end{array}$ & Medium (Sativa et.al., 2017) \\
\hline $\begin{array}{l}\text { Cabai } \\
\text { rawit }\end{array}$ & $\begin{array}{l}\text { Produk mudah rusak. } \\
\text { Penanganan pasca panen } \\
\text { menentukan masa simpan } \\
\text { dan kualitas sampai di } \\
\text { tangan konsumen (Samira } \\
\text { et.al., 2013). }\end{array}$ & $\begin{array}{l}\text { Sama dengan di pasar cabai merah (dari } \\
\text { petani sampai pada pedagang besar, } \\
\text { pasar bersifat oligopsoni, dan dari } \\
\text { pedagang besar sampai tingkat eceran } \\
\text { berstruktur oligopoly (JICA, 2018). }\end{array}$ & Relatif rendah (JICA, 2018). \\
\hline $\begin{array}{l}\text { Minyak } \\
\text { goreng }\end{array}$ & $\begin{array}{l}\text { Produk industri } \\
\text { pengolahan bahan baku } \\
\text { sawit dan memiliki masa } \\
\text { simpan yang relatif lama. }\end{array}$ & $\begin{array}{l}\text { Struktur pasar yang bersifat oligopsoni } \\
\text { di tahap awal dan berstruktur oligopoli } \\
\text { di tahapan-tahapan berikutnya di } \\
\text { sepanjang rantai pemasaran (JICA, } \\
\text { 2018). }\end{array}$ & $\begin{array}{l}\text { Intervensi di pasar bahan } \\
\text { baku (palm oil sector) relatif } \\
\text { tinggi (Pramudya et.al., 2017), } \\
\text { dan di bagian hilir (minyak } \\
\text { goreng) relatif rendah. }\end{array}$ \\
\hline Gula pasir & $\begin{array}{l}\text { Produk industri } \\
\text { pengolahan bahan baku } \\
\text { tebu, dan memiliki waktu } \\
\text { simpan yang relatif lama. }\end{array}$ & $\begin{array}{l}\text { Penjualan gula di tahapan awal rantai } \\
\text { pemasaran dilakukan dengan sistem } \\
\text { lelang dan dikuasai oleh BUMN. Di } \\
\text { sepanjang rantai pasar ditemukan } \\
\text { rembesan gula kristal rafinasi (gula } \\
\text { impor) ke pasar gula produk lokal } \\
\text { (JICA, 2018). }\end{array}$ & $\begin{array}{l}\text { Relatif tinggi (Rahman et.al., } \\
\text { 2018). }\end{array}$ \\
\hline
\end{tabular}

pasar tradisional. Secara ringkas marjin pemasaran (price spread) untuk masingmasing komoditas bahan pangan diwakili oleh rumus:

$$
P S_{i j t}=P_{i t}-P_{j t}
$$

Di mana $P S_{i j t}$ adalah marjin pemasaran antara pasar ke- $i$ dengan pasar ke $j$ di hari ke- $t, P_{i t}$ adalah harga bahan pangan di tingkat pasar ke $i$, dan $P_{j t}$ adalah harga bahan pangan di tingkat pasar $j$.

Data harga harian sebelum pandemi Covid-19 adalah harga pada saat dan sebelum tanggal pemerintah memberlakukan pembatasan sosial berskala besar (PSBB) yaitu tanggal 2 Januari 2020 - 9 April 2020. Sementara data saat pandemi Covid-19 dimulai pada tanggal 10 April 2020 - 13 Januari 2021. Aktivitas ekonomi masyarakat terasa berubah pada saat diterapkannya PSBB. Pemilihan waktu batas antara sebelum dan setelah pandemi Covid-19 dilakukan bukan pada saat pemerintah pertama kali mengumumkan kasus pertama SARS-Cov-2 di Indonesia.

Analisis terhadap data dilakukan melalui pemanfaatan metode statistik deskriptif yang berupa penghitungan rataan dan deviasi standar untuk memperoleh koefisien variasi berupa rumus berikut:

$$
\mathrm{CV}=\frac{s}{x} \boldsymbol{x} 100 \%
$$

Dimana CV adalah koefisien variasi, $\mathrm{s}$ merupakan standar deviasi, dan $\mathrm{x}$ adalah ratarata sampel.

Komoditas atau bahan pangan yang dikaji adalah beras, bawang merah, bawang putih, cabai merah, cabai rawit, minyak goreng, dan gula pasir. Berdasarkan hasil perhitungan rataan, deviasi standar, dan koefisien variasi terhadap masing-masing bahan pangan, kemudian dilakukan komparasi dan interpretasi. 


\section{HASIL DAN PEMBAHASAN}

\section{POLA PERUBAHAN HARGA}

Kondisi permintaan dan penawaran serta perbedaan struktur pasar masing-masing bahan pangan menjadikan perubahan pola perubahan harga yang berbeda-beda. Pandemi Covid-19 dan kebijakan pembatasan dan pengetatan aktivitas penduduk berpengaruh pada permintaan dan pada penawaran yaitu melalui terganggunya aliran barang. Pada
Tabel 3, jika dibandingkan rataan harga di tingkat konsumen (yaitu, pasar modern dan pasar tradisional) sebelum dan setelah adanya pandemi Covid-19, dari 7 komoditas bahan pangan yang diteliti terdapat dua komoditas yang meningkat harganya, yaitu harga bawang merah dan minyak goreng. Peningkatan harga dapat disebabkan karena faktor musim ataupun faktor terganggunya pasokan produk dari produsen ke pasar konsumen. Bersumber dari berita berbagai media massa

Tabel 3. Rata-Rata dan Koefisien Variasi Harga Pangan di Berbagai Tingkat Pasar Sebelum dan Setelah Adanya Pandemi Covid-19

\begin{tabular}{|c|c|c|c|c|}
\hline \multirow{2}{*}{$\begin{array}{c}\text { Komoditas dan } \\
\text { Tingkat Pasar }\end{array}$} & \multicolumn{2}{|c|}{$\begin{array}{c}\text { Harga Sebelum Pandemi } \\
\text { Covid-19 }\end{array}$} & \multicolumn{2}{|c|}{$\begin{array}{c}\text { Harga Setelah Pandemi } \\
\text { Covid-19 }\end{array}$} \\
\hline & $\begin{array}{l}\text { Rata-rata } \\
\text { (Rp) }\end{array}$ & $\begin{array}{c}\text { Koefisien Variasi } \\
(\%)\end{array}$ & $\begin{array}{l}\text { Rata-rata } \\
\text { (Rp) }\end{array}$ & $\begin{array}{c}\text { Koefisien Variasi } \\
(\%)\end{array}$ \\
\hline \multicolumn{5}{|l|}{ Beras } \\
\hline 1. Produsen & 9.904 & 6,2 & 9.497 & 6,6 \\
\hline 2. Pedagang Besar & 10.924 & 0,4 & 10.894 & 0,7 \\
\hline 3. Pasar Modern & 14.213 & 1,5 & 13.943 & 0,2 \\
\hline 4. Pasar Tradisional & 11.851 & 0,2 & 11.838 & 0,4 \\
\hline \multicolumn{5}{|l|}{ Bawang Merah } \\
\hline 1. Produsen & 23.850 & 5,8 & 26.228 & 25,1 \\
\hline 2. Pedagang Besar & 30.045 & 4,9 & 30.990 & 22,8 \\
\hline 3. Pasar Modern & 49.114 & 6,0 & 54.207 & 15,9 \\
\hline 4. Pasar Tradisional & 38.576 & 4,1 & 39.041 & 20,4 \\
\hline \multicolumn{5}{|l|}{ Bawang Putih } \\
\hline 1. Produsen & 14.650 & 0 & 7.815 & 23,3 \\
\hline 2. Pedagang Besar & 34.836 & 16,2 & 21.680 & 21,5 \\
\hline 3. Pasar Modern & 49.133 & 17,8 & 39.290 & 22,2 \\
\hline 4. Pasar Tradisional & 43.305 & 15,3 & 28.857 & 18,2 \\
\hline \multicolumn{5}{|l|}{ Cabai Merah } \\
\hline 1. Produsen & 25.541 & 17,1 & 21.906 & 30,7 \\
\hline 2. Pedagang Besar & 34.139 & 16,7 & 27.855 & 27,5 \\
\hline 3. Pasar Modern & 72.876 & 5,3 & 57.488 & 13,2 \\
\hline 4. Pasar Tradisional & 43.619 & 13,8 & 37.218 & 22,2 \\
\hline \multicolumn{5}{|l|}{ Cabai Rawit } \\
\hline 1. Produsen & 29.086 & 16,1 & 25.030 & 22,3 \\
\hline 2. Pedagang Besar & 36.360 & 16,1 & 28.642 & 25,3 \\
\hline 3. Pasar Modern & 74.583 & 4,1 & 59.151 & 12,9 \\
\hline 4. Pasar Tradisional & 46.666 & 15,2 & 37.636 & 23,3 \\
\hline \multicolumn{5}{|l|}{ Minyak Goreng } \\
\hline 1. Produsen & 10.712 & 3,0 & 11.098 & 6,2 \\
\hline 2. Pedagang Besar & 12.303 & 1,3 & 12.560 & 2,6 \\
\hline 3. Pasar Modern & 15.407 & 1,2 & 15.975 & 2,1 \\
\hline 4. Pasar Tradisional & 13.755 & 0,6 & 13.960 & 2,2 \\
\hline \multicolumn{5}{|l|}{ Gula Pasir } \\
\hline 1. Produsen & 12.244 & 7,8 & 11.940 & 9,5 \\
\hline 2. Pedagang Besar & 13.928 & 9,6 & 13.665 & 10,0 \\
\hline 3. Pasar Modern & 13.665 & 3,5 & 14.014 & 4,2 \\
\hline 4. Pasar Tradisional & 15.384 & 8,9 & 15.347 & 8,8 \\
\hline
\end{tabular}


yang terbit di bulan Mei 2020 dapat diketahui bahwa musim tanam bawang merah di tahun 2020 di sentra produksi Brebes mundur sekitar satu bulan, yaitu menjadi tanam mulai bulan Februari. Seperti halnya Saliem et.al., (2020) bahwa mundurnya masa tanam bawang merah sejak tahun 2019 menyebabkan panen raya bertepatan dengan curah hujan tinggi. Sehingga menyebabkan produktivitas turun. Harga bawang merah menunjukkan peningkatan tajam di bulan April sampai bulan Juni, saat bawang merah mulai panen, dan kemudian harga turun saat hasil panen mulai memasuki pasar. Meskipun relatif stabil, harga minyak goreng sedikit mengalami peningkatan apabila dibandingkan rata-rata harga sebelum Covid-19 dengan rata-rata harga setelah Covid-19.

Pola perubahan harga tidak saja berbeda antar komoditas tetapi dapat juga antar tingkatan pasar pada komoditas yang sama tidak menunjukkan arah pergerakan yang sama. Kecuali gula pasir, semua tingkatan pasar di sepanjang rantai pemasaran masingmasing komoditas pangan menunjukkan arah perubahan yang sama. Harga rata-rata gula pasir sebelum pandemi Covid-19 lebih tinggi daripada rata-rata harga gula pasir setelah pandemi Covid-19 di semua tingkatan pasar, kecuali di pasar modern. Harga gula pasir di pasar modern rata-rata lebih tinggi setelah adanya pandemi Covid-19, yaitu meningkat sebesar 2,5 persen dibanding rata-rata harga sebelum pandemi Covid-19. Sedangkan pada saat yang sama, harga di tingkat pasar tradisional, maupun harga di tingkat pasar di bawahnya (produsen dan pedagang besar), mengalami sedikit penurunan. Pedagang di pasar modern dapat dikatakan tidak sepenuhnya bertindak sebagai penerima harga pasar. Gula pasir yang dijual di pasar modern juga dapat berbeda per kilogram tergantung pada kualitas dan asal ataupun jenama (brand) gula yang tercantum dalam kemasan. Perilaku penentuan harga di tingkat pasar modern, terutama supermarket, pada umumnya memang tidak mengikuti teori pasar bersaing. Sehingga harga yang turun di tingkat pasar produsen ataupun pedagang besar belum tentu direspon dengan turunnya harga di tingkat eceran.

Tabel 3 juga menyajikan informasi penting, yaitu variasi harga di pasar beras relatif lebih rendah daripada variasi harga di pasar komoditas pangan lainnya, baik sebelum atau pun semasa adanya pandemi Covid-19. Pasar beras memperoleh intervensi pemerintah yang relatif lebih intensif dibandingkan pasar bahan pangan lainnya. Berbagai kebijakan diambil untuk menciptakan stabilitas harga beras di tingkat konsumen. Kebijakan pemeri-tah dalam stabilisasi harga konsumen ini tampaknya berhasil memperkecil dampak pandemi Covid-19 terhadap fluktuasi harga beras. Jika dibandingkan fluktuasi harga sebelum dan setelah adanya pandemi Covid19, terlihat bahwa fluktuasi harga hanya sedikit mengalami kenaikan dibandingkan dengan fluktuasi harga bahan pangan lainnya. Fluktuasi harga beras di tingkat pasar modern bahkan mengalami penurunan, yaitu dari 1,5 persen menjadi 0,2 persen. Pelaku di pasar modern tampaknya mengikuti imbauan pemerintah untuk turut menstabilkan harga beras di saat pandemi, sehingga pergerakan harganya lebih stabil dibandingkan dengan harga di pasar tradisional. Namun upaya pemerintah untuk melakukan stabilisasi harga terlihat belum cukup berhasil di tingkat produsen. Koefisien harga di tingkat produsen masih jauh lebih tinggi dibandingkan dengan koefisien variasi di tingkat pasar yang lain di sepanjang rantai pemasaran beras.

Apabila harga-harga pangan cenderung turun setelah adanya Covid-19, namun fluktuasi harga cenderung meningkat. Berdasarkan Gambar 1 diketahui bahwa semua harga komoditas pangan dalam penelitian ini memiliki koefisien variasi yang lebih besar pada masa pandemi Covid-19 dibandingkan dengan kondisi sebelumnya. Lonjakan koefisien variasi terutama dialami oleh komoditas pangan yang mudah rusak (perishable), seperti cabai merah, cabai rawit, bawang merah, dan bawang putih. Bahkan untuk kasus bawang putih, harga di tingkat produsen tidak mengalami perubahan dari hari ke hari di sepanjang sebelum adanya pandemi Covid-19 (koe- 


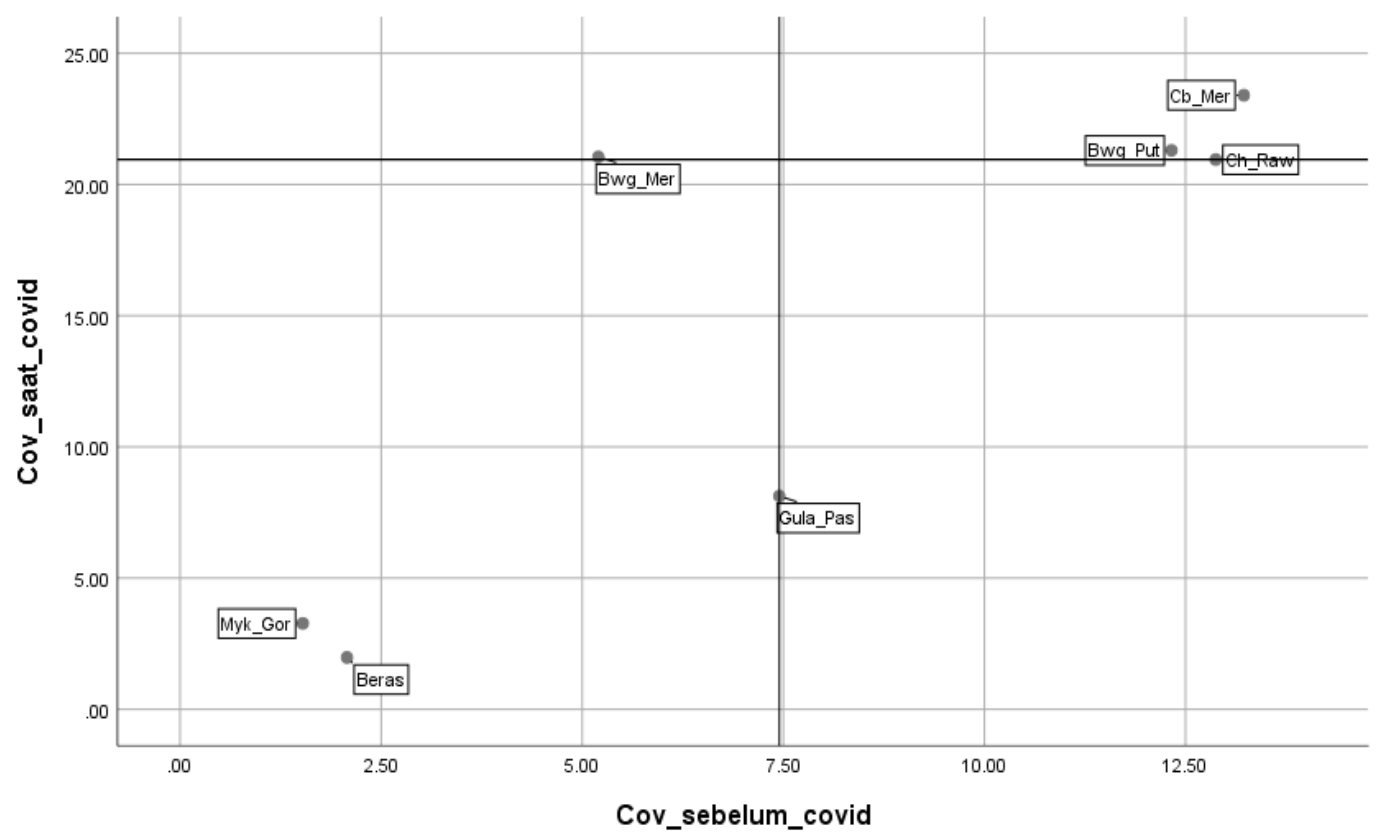

\section{Gambar 1. Rataan Nilai Koefisien Variasi Komoditas Pangan Sebelum dan pada Saat Pandemi Covid-19}

fisien variasi $=0$ ) dan harga menjadi berfluktuasi setelah pandemi Covid-19 terjadi.

Meningkatnya variasi harga-harga pangan setelah adanya pandemi Covid-19 dapat menjadi bukti adanya gangguan aliran barang antar daerah maupun antar tingkat pasar di sepanjang rantai pemasaran. Pandemi Covid19 dan kebijakan pembatasan aktivitas dan pergerakan manusia (PSBB) tampaknya telah mempengaruhi aliran barang, sehingga penambahan pasokan barang menjadi kurang responsif pada saat di suatu daerah mengalami kenaikan harga. Fluktuasi harga bahan pangan yang mudah rusak yang meningkat tidak saja dapat menjadi indikasi terganggunya aliran barang, tetapi juga mencerminkan semakin "terlokalisasinya" pasar bahan pangan. Pengalaman di negara lain menunjukkan pasar bahan pangan yang bersifat mudah rusak mengalami lonjakan-lonjakan harga yang memang lebih besar daripada harga pangan yang bersifat non-perishable, seperti gandum (Varshney et.al., 2020).

Sementara variasi harga pangan yang nonperishable juga mengalami peningkatan. Namun peningkatannya tidak lebih tinggi dari variasi harga komoditas pangan. Merujuk pada hasil analisis yang dilakukan oleh
Pramudya et.al., 2017, Nuryanti, 2018, dan Rahman et.al., 2018 bahwa ketiga komoditas pangan non-perishable yaitu minyak goreng, beras dan gula pasir memiliki pengaruh intervensi pemerintah yang relatif lebih tinggi.

\section{POLA PERUBAHAN MARJIN PEMASARAN}

Pandemi Covid-19 tidak saja mengubah harga-harga di berbagai tingkatan pasar di sepanjang rantai pemasaran, tetapi juga mengubah besaran marjin pemasarannya. Tabel 4 menyajikan rata-rata dan koefisien variasi marjin pemasaran (price spread) antar pasar di sepanjang rantai pemasaran bahan pangan. Rata-rata marjin pemasaran antar tingkatan pasar di sepanjang rantai pemasaran berbedabeda antar komoditas. Rata-rata marjin pemasaran yang tinggi terutama terjadi pada pasar bahan pangan yang mudah rusak, seperti bawang merah, bawang putih, cabai merah, dan cabai rawit. Marjin pemasaran disusun oleh dua faktor, yaitu biaya-biaya pemasaran dan marjin keuntungan yang diambil oleh para pelaku pemasaran. Bahan pangan yang mudah rusak tentunya memerlukan biaya-biaya pemasaran yang lebih ting- 
gi dalam bentuk sortasi, pengemasan dan penanganan (packaging and handling), ataupun tingkat kerusakan (susut) yang tinggi selama pergerakan barang sampai di tangan konsumen. Marjin pemasaran di antara tingkat produsen dan pasar modern, untuk komoditas pangan bawang merah, bawang putih, cabai merah, dan cabai rawit, bahkan lebih besar daripada harga di tingkat produsen. Dengan kata lain, produsen bawang merah ataupun bawang putih menerima harga untuk produk yang dihasilkannya lebih kecil daripada biaya-biaya dan keuntungan yang terjadi di sepanjang rantai pemasaran. Sedangkan bawang merah ataupun bawang putih sejak dari produsen sampai produk tiba di tangan konsumen tidak mengalami perubahan bentuk (pengolahan) yang berarti, yang terjadi hanyalah perubahan waktu (simpan) dan perubahan tempat (transportasi). Marjin pemasaran yang besar ini dapat menjadi indikasi belum efisiennya rantai pasar di komoditas bahan pangan. Keadaan ini semakin parah saat terjadi pandemi Covid-19, dimana marjin pemasaran antara tingkat produsen dan pasar modern semakin melebar dan semakin meningkat risikonya, yang ditunjukkan oleh meningkatnya koefisien variasinya.

Rata-rata marjin pemasaran antar tingkatan pasar lebih tinggi di periode setelah Covid-19 dibandingkan dengan periode sebelum adanya Covid-19. Hal ini dapat menjadi indikasi bahwa pandemi Covid-19 menyebabkan meningkatnya biaya pemasaran komoditas pangan. Namun tidak semua marjin pemasaran mengalami peningkatan pada masa pandemi. Penurunan besaran marjin pemasaran terjadi pada umumnya antara tingkat produsen dengan pasar tradisional. Turunnya marjin pemasaran antara tingkat produsen dengan tingkat pasar tradisional menandakan bahwa para pelaku di pasar tradisional menurunkan marjin keuntungan yang diperolehnya pada saat permintaan pasar turun akibat Covid-19.

Pada Tabel 4 menunjukkan adanya marjin pemasaran yang negatif di pasar gula pasir, yaitu marjin antara pedagang besar dengan pasar modern. Marjin negatif terjadi karena pedagang besar menjual dengan harga yang lebih rendah kepada pelaku di pasar modern. Hal ini dapat dilihat pada Tabel 3, di mana rata-rata harga gula pasir lebih tinggi di tingkat pedagang daripada harga di tingkat produsen. Pada Tabel 3 dapat dilihat bahwa rata-rata harga gula pasir di tingkat pedagang besar sebelum pandemi Covid-19 lebih tinggi daripada harga rata-rata di tingkat eceran pasar modern. Di pasar gula pasir, rata-rata marjin antara pedagang besar dan pasar modern juga menunjukkan besaran yang paling rendah, baik periode sebelum maupun setelah pandemi.

Kecuali pasar di pasar beras dan gula pasir, koefisien variasi marjin pemasaran komoditas pangan menunjukkan peningkatan setelah adanya pandemi Covid-19. Peningkatan variasi marjin pemasaran ini juga dapat menjadi indikasi semakin meningkatnya risiko yang dihadapi para pelaku yang berada di sepanjang rantai pemasaran bahan pangan. Koefisien variasi marjin pemasaran beras dan gula menunjukkan upaya kebijakan pengendalian harga yang dilakukan pemerintah menunjukkan hasil, terutama di pasar beras. Meskipun turun, pada Tabel 4 koefisien variasi marjin pemasaran di pasar gula di periode sebelum dan semasa pandemi menunjukkan angka yang relatif tinggi. Tingginya variasi marjin pemasaran, terutama marjin antara pedagang besar dengan pasar modern, menunjukkan stabilisasi harga di pasar gula pasir masih memiliki potensi besar untuk ditingkatkan. Variasi marjin antara pedagang besar dan pasar tradisional jauh lebih rendah daripada variasi marjin antara pedagang besar dengan pasar modern. Perbaikan kelembagaan diperlukan untuk meningkatkan kompetisi yang terjadi di pasar gula pasir. Sebagaimana ditunjukkan oleh laporan penelitian JICA (2018), pasar gula pasir cenderung berstruktur oligopolistik, dan adanya rembesan produk gula kristal rafinasi ke dalam pasar gula kristal putih juga meningkatkan ketidakpastian pasokan di pasar. 
Tabel 4. Rata-Rata dan Koefisien Variasi Marjin Pemasaran Antar Tingkat Pasar Sebelum dan Setelah Adanya Pandemi Covid-19

\begin{tabular}{|c|c|c|c|c|}
\hline \multirow{2}{*}{$\begin{array}{c}\text { Komoditas dan Antar } \\
\text { Tingkat Pasar }\end{array}$} & \multicolumn{2}{|c|}{$\begin{array}{c}\text { Marjin Sebelum Pandemi } \\
\text { Covid-19 }\end{array}$} & \multicolumn{2}{|c|}{$\begin{array}{c}\text { Marjin Setelah Pandemi } \\
\text { Covid-19 }\end{array}$} \\
\hline & $\begin{array}{c}\text { Rata-rata } \\
(\mathrm{Rp})\end{array}$ & $\begin{array}{c}\text { Koefisien Variasi } \\
(\%)\end{array}$ & $\begin{array}{l}\text { Rata-rata } \\
(\mathbf{R p})\end{array}$ & $\begin{array}{c}\text { Koefisien Variasi } \\
(\%)\end{array}$ \\
\hline \multicolumn{5}{|l|}{ Beras } \\
\hline 1. Produsen/P.Besar & 1.022 & 61,1 & 1.397 & 44,7 \\
\hline 2. Produsen/P.Modern & 4.309 & 14,4 & 4.445 & 14,1 \\
\hline 3. Produsen/P.Tradisional & 1.947 & 31,7 & 2.341 & 26,6 \\
\hline 4. P.Besar/P.Modern & 3.287 & 7,6 & 3.048 & 2,6 \\
\hline 5. P.Besar/P.Tradisional & 925 & 3,9 & 944 & 4,4 \\
\hline \multicolumn{5}{|l|}{ Bawang Merah } \\
\hline 1. Produsen/P.Besar & 6.195 & 29,4 & 4.761 & 113,0 \\
\hline 2. Produsen/P.Modern & 25.264 & 9,4 & 27.978 & 19,4 \\
\hline 3. Produsen/P.Tradisional & 14.726 & 12,9 & 12.812 & 47,4 \\
\hline 4. P.Besar/P.Modern & 19.069 & 13,4 & 23.216 & 25,3 \\
\hline 5. P.Besar/P.Tradisional & 8.530 & 6,5 & 8.050 & 15,7 \\
\hline \multicolumn{5}{|l|}{ Bawang Putih } \\
\hline 1. Produsen/P.Besar & 20.186 & 27,9 & 13.864 & 23,9 \\
\hline 2. Produsen/P.Modern & 34.483 & 25,3 & 31.474 & 23,0 \\
\hline 3. Produsen/P.Tradisional & 28.655 & 23,1 & 21.041 & 18,2 \\
\hline 4. P.Besar/P.Modern & 14.297 & 42,7 & 1.761 & 33,0 \\
\hline 5. P.Besar/P.Tradisional & 8.469 & 27,8 & 7.177 & 14,0 \\
\hline \multicolumn{5}{|l|}{ Cabai Merah } \\
\hline 1. Produsen/P.Besar & 8.597 & 54,6 & 5.948 & 81,2 \\
\hline 2. Produsen/P.Modern & 47.334 & 9,3 & 35.582 & 25,1 \\
\hline 3. Produsen/P.Tradisional & 18.077 & 30,1 & 15.312 & 34,9 \\
\hline 4. P.Besar/P.Modern & 38.736 & 17,7 & 29.633 & 32,4 \\
\hline 5. P.Besar/P.Tradisional & 9.480 & 20,1 & 9.363 & 15,9 \\
\hline \multicolumn{5}{|l|}{ Cabai Rawit } \\
\hline 1. Produsen/P.Besar & 7.274 & 71,6 & 3.612 & 170,4 \\
\hline 2. Produsen/P.Modern & 45.497 & 7,9 & 34.121 & 24,8 \\
\hline 3. Produsen/P.Tradisional & 17.580 & 41,2 & 12.606 & 56,7 \\
\hline 4. P.Besar/P.Tradisional & 38.222 & 15,5 & 30.509 & 28,9 \\
\hline 5. P.Besar/P.Tradisional & 10.306 & 27,5 & 8.994 & 23,8 \\
\hline \multicolumn{5}{|l|}{ Minyak Goreng } \\
\hline 1. Produsen/P.Besar & 1.591 & 19,9 & 1.461 & 31,5 \\
\hline 2. Produsen/P.Modern & 4.694 & 5,8 & 4.876 & 9,3 \\
\hline 3. Produsen/P.Tradisional & 3.042 & 9,7 & 2.861 & 16,4 \\
\hline 4. P.Besar/P.Modern & 3.103 & 6,0 & 3.415 & 3,2 \\
\hline 5. P.Besar/P.Tradisional & 1.451 & 9,9 & 1.400 & 3,2 \\
\hline \multicolumn{5}{|l|}{ Gula Pasir } \\
\hline 1. Produsen/P.Besar & 1.683 & 39,3 & 1.724 & 32,2 \\
\hline 2. Produsen/P.Modern & 1.420 & 41,4 & 2.073 & 33,2 \\
\hline 3. Produsen/P.Tradisional & 3.139 & 22,3 & 3.406 & 15,7 \\
\hline 4. P.Besar/P.Modern & -263 & 327,8 & 348 & 236,5 \\
\hline 5. P.Besar/P.Tradisional & 1455 & 13,7 & 1.681 & 5,1 \\
\hline
\end{tabular}

\section{KESIMPULAN DAN SARAN}

\section{KESIMPULAN}

1. Pada umumnya, harga-harga bahan pangan di tingkat eceran menunjukkan penu- runan jika dibandingkan antara harga ratarata pada periode sebelum dan harga ratarata periode saat adanya pandemi Covid19. Penurunan harga ini dapat menjadi indikasi melemahnya permintaan bahan 
pangan di tingkat konsumen. Namun pada sisi yang lain, kecenderungan turunnya harga ini disertai dengan fluktuasi harga yang semakin besar. Hal ini ditunjukkan oleh koefisien variasi harga-harga bahan pangan yang semakin besar di periode pandemi.

2. Marjin pemasaran pada pasar bahan pangan yang bersifat mudah rusak (bawang merah, bawang putih, cabai merah, dan cabai rawit) relatif lebih besar daripada marjin pemasaran bahan pangan yang nonperishable (beras, minyak goreng, dan gula pasir), baik dalam besaran absolutnya maupun berdasarkan persentase dari harga di tingkat produsen. Kecuali pasar bawang merah dan gula pasir, marjin pemasaran tidak saja meningkat besarannya pada periode setelah adanya pandemi Covid-19, tetapi juga menunjukkan variabilitas yang meningkat.

\section{SARAN}

Peningkatan variasi marjin pemasaran dapat menjadi indikasi semakin meningkatnya risiko yang dihadapi para pelaku yang berada di sepanjang rantai pemasaran bahan pangan. Sehingga perbaikan kelembagaan diperlukan untuk meningkatkan kompetisi yang terjadi di pasar, khususnya pasar di pasar gula pasir. Kebijakan impor bawang putih dan gula pasir rafinasi tampaknya berperan dalam mengurangi variabilitas marjin pemasaran di kedua komoditas ini.

\section{DAFTAR PUSTAKA}

Amanda, D., Syaukat, Y., \& Firdaus, M. (2016). Estimating the Market Power in the Indonesian Garlic Industry. Journal of the International Society for Southeast Asian Agricultural Sciences, 22(2), 66-79.

Huang, J. (2020). Impacts of COVID-19 on agriculture and rural poverty in China. Journal of Integrative Agriculture, 19(12): 2849-2853. https://doi.org/10.1016/S20953119(20)63469-4
JICA. 2018. Market study on food sector in Indonesia. Indonesia.

Min, S., Xiang, C., \& Zhang, X. H. (2020). Impacts of the COVID-19 pandemic on consumers' food safety knowledge and behavior in China. Journal of Integrative Agriculture, 19 (12): 2926-2936. https://doi.org/10.1016/S20953119(20)63388-3.

Nchanji, E., Lutomia, C. K., Chirwa, R., Templer, N., Rubyogo, J. C., \& Onyango, P. (2020). Immediate impacts of COVID19 pandemic on bean value chain in selected countries in sub-Saharan Africa. Agricultural Systems, 103034. https://doi.org/10.1016/j.agsy.2020.103 034.

Nurjanah, R., Purwanto, Y.A. \& Sutrisno. (2014). Pengaruh jenis kemasan dan penyimpanan dingin terhadap mutu fisik cabai merah. Jurnal Pascapanen, 11(1):1929.

Nuryanti, S. (2018). Swasembada Beras Berkelanjutan: Dilema antara Stabilisasi Harga dan Distribusi Pendapatan. Forum Penelitian Agro Ekonomi, 35(1), 19-30. https://dx.doi.org/10.21082/fae.v35n1. 2017.19-30\%201.

Pahulu, H. F., Davidson, R. T., Dunn, M. L., Ogden, L. V., Steele, F. M., \& Pike, O. A. (2007). Change in Mutagenicity in White Rice after Accelerated and Long-Term Storage. Journal of food science, 72(2), C126C131. https://doi.org/10.1111/j.17503841.2006.00259.x.

Pan, D., Yang, J., Zhou, G., \& Kong, F. (2020). The influence of COVID-19 on agricultural economy and emergency mitigation measures in China: A text mining analysis. PloS one, 15(10), e0241167. https://doi.org/10.1371/journal.pone.0 241167.

Pangaribowo, E. H. (2014). Consumption Behavior of the Poorest and Policy Implications in Indonesia. In Marginality (pp. 221-237). Springer, Dordrecht. 
https://doi.org/10.1007/978-94-007-

7061-4_14.

Poudel, P. B., Poudel, M. R., Gautam, A., Phuyal, S., Tiwari, C. K., Bashyal, N., \& Bashyal, S. (2020). COVID-19 and its Global Impact on Food and Agriculture. Journal of Biology and Today's World, 9(5), 221.

Rahman, M. E., Sinaga, B. M., \& Susilowati, S. H. (2019). Kebijakan Dukungan Domestik untuk Menetralisir Dampak Negatif Penurunan Tarif Impor Terhadap Industri Gula Indonesia. Jurnal Agro Ekonomi, 36(2), 91-112. DOI: http://dx.doi.org/10.21082/jae.v36n2.2 018.91-112

Rahmawati, A., Fariyanti, A., \& Rifin, A. (2018). Spatial Market Integration of Shallot in Indonesia. Jurnal Manajemen $\mathcal{E}$ Agribisnis, 15(3), 258258. https://doi.org/10.17358/jma.15.3 .258 .

Sahoo, J.P., \& Samal, K. (2020). Impacts of Covid-19 on Indian Agriculture. Agriculture Letters, 1(3):45-46.

Saliem, H. P., Agustian, A., \& Perdana, R. P. (2020). Dinamika harga, permintaan, dan upaya pemenuhan pangan pokok pada era pandemi Covid-19. Draft makalah Buku Bunga Rampai Covid-19. Bogor (ID): Pusat Sosial Ekonomi dan Kebijakan Pertanian.

Samira, A., Woldetsadik, K., \& Workneh, T. S. (2013). Postharvest quality and shelf life of some hot pepper varieties. Journal of food science and technology, 50(5), 842-855. https://doi.org/10.1007/s13197-0110405-1.

Sativa, M., Harianto, \& Suryana, A. (2017). Impact of red chilli reference price policy in Indonesia. International Journal of Agriculture System, 5(2): 120-139. http://dx.doi.org/10.20956/ijas.v5i2.12 01.

Siche, R. (2020). What is the impact of COVID19 disease on agriculture? Scientia Agropecuaria, 11(1), 3-6. http://dx.doi.org/10.17268/sci.agropec u.2020.01.00.

Tanger, S. (2020). Economic Impacts of COVID19 on Food and Agricultural Markets. Technical Report.

Tesfa, T., Woldetsadik, K., \& Bayu, W. (2015). Shallot yield, quality and shelf-life as affected by Nitrogen fertilizer. International Journal of Vegetable Science, 21(5):454-466.

DOI:10.1080/19315260.2014.895790.

Urumugam, U., Kanagavalli, G., \& Manida, M. (2020). Covid-19: Impact of agriculture in India. Aegaeum Journal, 8(5): $480-488$. https:/ / ssrn.com/abstract=3600813.

Varshney, D., Roy, D., \& Meenakshi, J. V. (2020). Impact of COVID-19 on agricultural markets: assessing the roles of commodity characteristics, disease caseload and market reforms. Indian economic review, 55(1), 83-103. https://doi.org/10.1007/s41775-02000095-1.

Vatsyayan, S., Brar, P.S., \& Dhali, R.K. (2014). Assessment of shelf life of garlic (Allium Satioum L.) ecotypes. Indian Journal of Ecology, 41(2):385-388.

Zhou, J. H., Han, F., Li, K., \& Wang, Y. (2020). Vegetable production under COVID-19 pandemic in China: An analysis based on the data of 526 households. Journal of Integrative Agriculture, 19 (12): 2854-2865. DOI: 10.1016/S2095-3119(20)63366-4. 